\title{
Cellulose Framework Directed Construction of Hierarchically Porous Carbons Offering High-Performance Capacitive
}

\section{Deionization of Brackish Water}

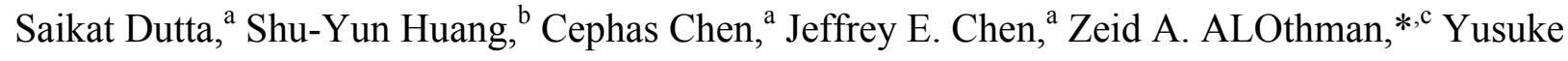
Yamauchi, ${ }^{\mathrm{d}}$ Chia-Hung Hou*,b and Kevin C.-W. Wu*,a

${ }^{\mathrm{a}}$ Department of Chemical Engineering, National Taiwan University, No 1, Sec 4, Roosevelt Rd. Taipei, Taiwan 10617

${ }^{\mathrm{b}}$ Graduate Institute of Environmental Engineering, National Taiwan University, Taipei, Taiwan 10617

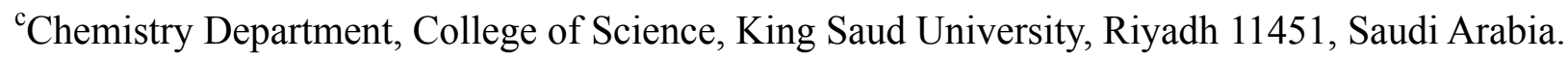

${ }^{\mathrm{d}}$ World Premier International (WPI) Research Center for Materials Nanoarchitectonics (MANA), National Institute for Materials Science (NIMS), 1-1 Namiki, Tsukuba, Ibaraki 305-0044, Japan.

\section{Experimental Details}

\section{Electrochemical measurement}

A CH instruments Model of 627D electrochemical workshop was conducted to perform the electrochemical experiments, including electrochemical impedance spectra (EIS), galvanostatic charge/discharge (GC) and cyclic voltammetry (CV) measurements. All the electrochemical properties were measured using a three-electrode cell system in a $\mathrm{NaCl}$ solution. The working and counter electrodes were a small and a large piece of carbons, respectively. An $\mathrm{Ag} / \mathrm{AgCl}$ (sat.) (CHI 111) act as the reference electrode. Electrochemical impedance spectra (EIS) measurement was performed to determine the electrical conductivity of the carbon electrode. The data was collected in the frequency range from $10 \mathrm{mHz}$ to $100 \mathrm{kHz}$ with $5 \mathrm{mM}$ a amplitude. The $\mathrm{GC}$ test was used to measure the reversibility and inner resistance (iR drop) of the carbon 
electrode. Voltage profiles were obtained at a current density of $100 \mathrm{~m} \mathrm{~A} / \mathrm{g}$ in the potential range of -0.4 to $0.6 \mathrm{~V}$. The $\mathrm{CV}$ measurement was executed in the evaluation of capacitive performance of the carbon electrode. Cyclic voltammograms for assessing the EDL capacitance were measured in a potential window 0.6 to $-0.4 \mathrm{~V}$ at various scan rate, ranging from 5 to 1000 $\mathrm{mV} \mathrm{s}^{-1}$. The specific capacitance derived from the CV curves can be estimated according to the following equation:

$$
C=\frac{\int_{V_{\mathrm{a}}}^{V_{\mathrm{c}}} I \mathrm{~d} V}{m v\left(V_{\mathrm{c}}-V_{\mathrm{a}}\right)}
$$

where $C$ is the specific capacitance, $v$ is the scan rate, $m$ is the mass of the carbon material, and $I$ is the current density. $V_{\mathrm{c}}$ and $V_{\mathrm{a}}$ represent the high and low potential limits of the cyclic voltammetry tests.

\section{CDI application}

The CDI electrodes were prepared by mixing a slurry of $90 \mathrm{wt} \%$ porous carbon powder and $10 \mathrm{wt} \%$ of polyvinylidene fluoride (PVDF, M.W. $=534,000$, Sigma-Aldrich) binder in N, NDimethylacetamide (DMAc, 99\%, Alfa Aesar) solution, followed by stirring for $12 \mathrm{~h}$ to ensure homogeneity. The slurry of the mixture was coated onto a titanium plate, dried in a $120^{\circ} \mathrm{C}$ oven for $2 \mathrm{~h}$ and in $80^{\circ} \mathrm{C}$ vacuum oven for $2 \mathrm{~h}$ to remove organic solvents.

The CDI experiments of NCs were conducted in a batch-mode recycling system, in which the $\mathrm{NaCl}$ solution was continuously circulated through the CDI unit cell using a peristaltic pump (EYELA MP-1000) at a flow rate of $5 \mathrm{~mL} \mathrm{~min}^{-1}$. The CDI unit cell consisted of a couple of carbon electrodes and a pair of titanium plates as the current collectors, which was separated by a spacer at a distance of $2 \mathrm{~mm}$ thickness for solution flow. Prior to each experiment, the CDI cell was flushing by $18-\Omega \mathrm{M}$ deionized water until the solution conductivity decreased to value near zero. The electrical voltage of $0.8,1.0$ or $1.2 \mathrm{~V}$ was applied to the two carbon electrodes using a CHI 627D potentiostat. The regeneration was carried out by discharging the cell at $0 \mathrm{~V}$. The change in solution conductivity was also continuously monitored at the outlet of the CDI cell by an online conductivity meter (SC-2300, Suntex). The concentration of the $\mathrm{NaCl}$ electrolyte was 
further determined by the linear relationship between the $\mathrm{NaCl}$ concentration and the conductivity in solution. The electrosorption capacity $(Q)$ is calculated as the following equation:

$Q=\frac{\left(C_{0}-C_{e}\right) \cdot V_{N a C l}}{m}$

where $C_{0}$ and $C_{\mathrm{e}}$ are the initial and equilibrium concentrations, respectively, and $V_{\mathrm{NaCl}}$ is the solution volume.

\section{Characterization}

SEM images of the samples were recorded by using a scanning electron microscope (Nova Nano SEM) operating at an acceleration voltage of $5.00 \mathrm{kV}$. High-resolution transmission electron microscopy (HR-TEM) images were obtained on a JEOL JEM-1210 system with an accelerating voltage of $200 \mathrm{kV}$. Thermo gravimetric analyze (TGA) of samples were conducted by using a SDT Q600 thermo gravimetric analyzer in $\mathrm{N}_{2}$ from room temperature to $900{ }^{\circ} \mathrm{C}$ at a heating rate of $10{ }^{\circ} \mathrm{C} \mathrm{min}^{-1}$. X-ray photoelectron spectroscopy was collected on a Thermo Scientific Spectrometer of type "Sigma Probe" and XPS spectra of the samples were further deconvoluted into several narrow-scan spectra of the $\mathrm{C} 1 \mathrm{~s}, \mathrm{O} 1 \mathrm{~s}$ and $\mathrm{N} 1 \mathrm{~s}$ by using the software Avantage Data System (Version 3.95). XRD patterns were performed on a D8 ADVANCE (Germany) using $\mathrm{Cu}-\mathrm{K} \alpha(0.15406 \mathrm{~nm})$ radiant ion. The porous properties were analyzed using nitrogen adsorption/desorption isotherms on a Micromeritics ASAP 2010 instrument. The specific surface area and pore size were calculated using the Brunauer-Emmet-Teller (BET) and Barrett-Joyner-Halenda (BJH) methods, respectively. The resulting PSD curves defined as $\mathrm{dV} / \mathrm{d}(\log \mathrm{D})$, where $\mathrm{V}$ is the adsorbed volume and $\mathrm{D}$ is the pore width. Micropore data of the HPCs were obtained in Micromeritics ASAP 2020 instrument and the data were analyzed by using Original Density Functional Theory Model by the method of Non-negative Regularization. Pore size distribution of cellulose-filter templates (CFTs) were measured using Mercury Porosimeter Model No. 9520 instrument and pore size distribution, pore volumes were analyzed using softwere AutoPore IV 9500 version 1.04. X-ray photoelectron spectroscopy (XPS) spectra were measured at room temperature using a Thermo Scientific instrument with Theta Probe with an Al Ka X-ray source of $1486.6 \mathrm{eV}$ (AlKaline) and take-off angle (TOA) was set to $53^{\circ}$, pass energy: $20 \mathrm{eV}$; energy step $0.05 \mathrm{eV}$; scan no.: 30 . The region of survey spectra is 0 to $1400 \mathrm{eV}$ and the region of high-resolution $\mathrm{N}$ 1s spectra is 392 to $410 \mathrm{eV}$. The percentage of $\mathrm{N}$ was 
calculated from the XPS survey spectrum by using N 1s peak. All the binding energies were calibrated via referencing to $\mathrm{C} 1 \mathrm{~s}$ binding energy $(285.0 \mathrm{eV})$. 


\section{Results and discussion}

Table S1. Yields of HPCs after KOH activation.

\begin{tabular}{|c|c|c|c|c|}
\hline Entry & Sample name & $\begin{array}{c}\text { Sample weight (g) of } \\
\text { RF-TPF@LCFT } \\
\text { before KOH } \\
\text { treatment }\end{array}$ & $\begin{array}{c}\text { KOH used (g) for } \\
20 \mathrm{~mL} 5 \mathrm{M} \\
\text { aqueous }\end{array}$ & $\begin{array}{c}\text { HPC-X yields after } \\
\text { KOH treatment (g) }\end{array}$ \\
\hline 1 & HPC-900 & 2.0 & 5.6 & 0.230 \\
\hline 2 & HPC-800 & 2.0 & 5.6 & 0.380 \\
\hline 3 & HPC-600 & 2.0 & 5.6 & 0.900 \\
\hline 4 & HPC-500 & 2.0 & 5.6 & 1.200 \\
\hline $\begin{array}{l}\text { a 1g RF-TPF@LCFT can be obtained from the synthesis process described in experimental } \\
\text { section }\end{array}$
\end{tabular}

Table S2. Hg intrusion porosimetry measurements of cellulose-filter template.

\begin{tabular}{ccccc}
\hline Sample & $\begin{array}{c}\text { Average Pore Diameter } \\
(\mathrm{nm})\end{array}$ & $\begin{array}{c}\text { Total Intrusion Volume } \\
\left(\mathrm{mLg}^{-1}\right)\end{array}$ & $\begin{array}{c}\text { Total Pore Area } \\
\left(\mathrm{m}^{2} \mathrm{~g}^{-1}\right)\end{array}$ & $\begin{array}{c}\text { Porosity } \\
(\%)\end{array}$ \\
\hline LCFT & 4274.7 & 1.49 & 1.395 & 65.32
\end{tabular}


Table S3. Chemical composition of HPCs measured by elemental analysis (EA) and X-ray photoelectron spectroscopy (XPS).

\begin{tabular}{|c|c|c|c|c|}
\hline Samples & & $\mathrm{C}(\mathrm{wt} \%)$ & $\mathrm{N}\left(w t^{0} \%\right)$ & $\mathrm{O}(\mathrm{wt} \%)$ \\
\hline \multirow{3}{*}{ HPC-900 } & EA & 76.30 & - & - \\
\hline & XPS & 71.43 & 1.86 & 26.71 \\
\hline & EDX & 90.21 & - & 6.20 \\
\hline \multirow{3}{*}{ HPC-800 } & EA & 74.78 & 1.51 & NA \\
\hline & XPS & 72.32 & 1.96 & 25.71 \\
\hline & EDX & 86.60 & & 10.28 \\
\hline \multirow{3}{*}{ HPC-600 } & EA & 70.93 & 8.79 & NA \\
\hline & XPS & 85.16 & 7.87 & 6.97 \\
\hline & EDX & 74.73 & 12.01 & 12.96 \\
\hline \multirow{3}{*}{ HPC-500 } & EA & 68.75 & 8.57 & NA \\
\hline & XPS & 77.05 & 8.45 & 14.5 \\
\hline & EDX & 74.05 & 15.39 & 9.95 \\
\hline
\end{tabular}


Table S4. Distribution (\%) of surface N-functional groups by fitting the $\mathrm{N}_{1 \mathrm{~s}}$ core level XPS spectra for the HPC samples.

\begin{tabular}{|c|c|c|c|c|c|}
\hline Samples & $\begin{array}{c}\mathrm{N}-6 \\
\text { (pyridinic) }\end{array}$ & $\begin{array}{c}\mathrm{N} 6+\mathrm{N} 5 \\
\text { (pyrridinic/pyrrolic) }\end{array}$ & N-5 (pyrrolic) & $\begin{array}{c}\mathrm{N}-\mathrm{Q} 1 \\
\text { (quarternary) }\end{array}$ & $\begin{array}{l}\text { N-oxide } \\
\text { (oxidized) }\end{array}$ \\
\hline $\begin{array}{c}\text { Band energy } \\
(\mathrm{eV})\end{array}$ & $396-398$ & $398-399$ & $399-400$ & $401-402$ & $>402$ \\
\hline HPC-500 & - & $398.35(9.82 \%)$ & $\begin{array}{c}399.81 \\
(90.17 \%)\end{array}$ & - & - \\
\hline HPC-600 & $\begin{array}{c}398.15 \\
397.75 \\
(4.44 \%)\end{array}$ & $398.75(33.79 \%)$ & $\begin{array}{c}400.05 \\
(49.68 \%)\end{array}$ & $\begin{array}{c}402.3 \\
(12.07 \%)\end{array}$ & - \\
\hline HPC-800 & $\begin{array}{c}397.8 \\
(9.18 \%)\end{array}$ & $398.6(15.3 \%)$ & $\begin{array}{c}399.45,400.4 \\
(66.83 \%)\end{array}$ & $\begin{array}{c}401.4 \\
(9.18 \%)\end{array}$ & - \\
\hline HPC-900 & - & - & $400.17(100 \%)$ & - & - \\
\hline HPC-600UA & - & $398.59(62.25 \%)$ & $\begin{array}{c}399.95 \\
(26.85 \%)\end{array}$ & $\begin{array}{c}400.85 \\
(10.85 \%)\end{array}$ & - \\
\hline
\end{tabular}


Table S5. Comparison of $\mathrm{NaCl}$ Electrosorption Capacity of porous electrodes by CDI method for brackish water.

\begin{tabular}{lllllll}
\hline $\begin{array}{l}\text { Carbon } \\
\text { Electrode }\end{array}$ & $\begin{array}{l}\text { Surface } \\
\text { Area } \\
\left(\mathrm{m}^{2} / \mathrm{g}\right)\end{array}$ & $\begin{array}{l}\text { Pore } \\
\text { volume } \\
\left(\mathrm{cm}^{3} / \mathrm{g}\right)\end{array}$ & $\begin{array}{l}\text { Initial NaCl } \\
\text { concentration } \\
(\mathrm{mg} / \mathrm{L})\end{array}$ & $\begin{array}{l}\text { Applied } \\
\text { voltage } \\
(\mathrm{V})\end{array}$ & $\begin{array}{l}\text { Electrosorption } \\
\text { capacity } \\
(\mathrm{mg} / \mathrm{g})\end{array}$ & References \\
\hline 3DGHPC & 384.4 & 0.73 & $\sim 25$ & 1.2 & 6.18 & [1] Wen. Et al., 2013 \\
3DG & 250.3 & 0.49 & $\sim 25$ & 1.2 & 4.41 & [1] Wen et al., 2013 \\
3DHPC & 1036.8 & 2.62 & $\sim 30$ & 2.0 & 2.16 & [2] Wen et al., 2012 \\
3DMGA & 339 & - & $\sim 50$ & 1.2 & 1.97 & [3] Wang et al., 2013 \\
& & & & 1.6 & 3.90 & \\
OMC & 844 & 0.90 & $\sim 25$ & 1.2 & 0.68 & [4] Zou et al., 2008 \\
AC & 968 & 0.59 & $\sim 25$ & 1.2 & 0.25 & [4] Zou et al., 2008 \\
Graphene & 488 & 51.01 & $\sim 25$ & 2.0 & 1.30 & [5] Li et al., 2010 \\
$\begin{array}{l}\text { Hierarchal } \\
\text { ACF }\end{array}$ & 428 & 0.138 & $\sim 90$ & 1.6 & 1.99 & [6] Wang et al., 2012 \\
$\begin{array}{l}\text { Hierarchal } \\
\text { OMC }\end{array}$ & 410 & - & $\sim 4000$ & 1.2 & 14 & [7] Mayes, et al., 2010 \\
HPC-800 & 2535 & 1.50 & $\sim 30$ & 1.2 & 3.24 & This work \\
& & & $\sim 580$ & 1.2 & 7.75 & \\
\hline
\end{tabular}



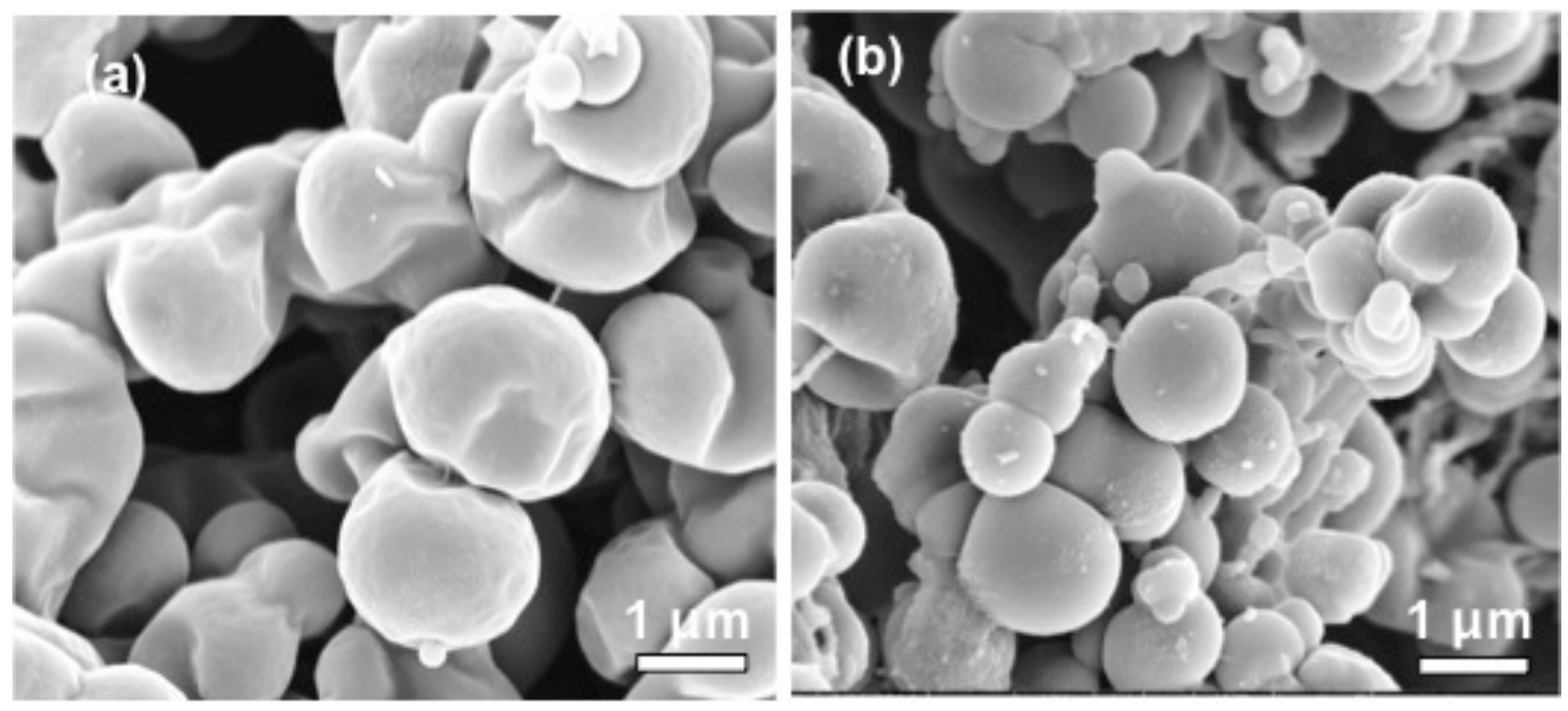

Figure S1. SEM images of HPC-600 synthesized without using the LCFT template (i.e., HPC$600 \mathrm{NT}$ ) (a) or without using KOH treatment (i.e., HPC-600UA) (b). 

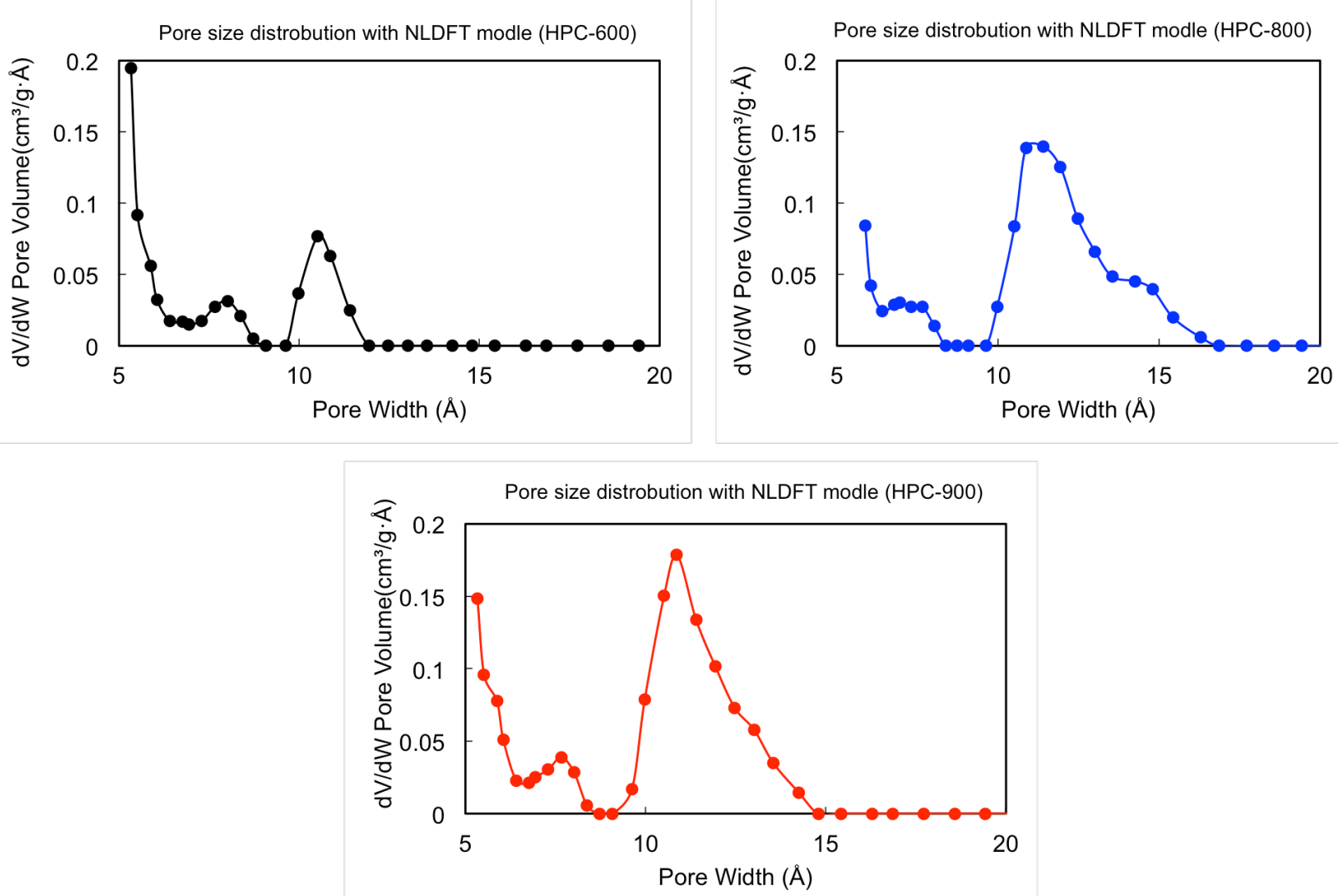

Figure S2. Micropore size distributions of HPC-600, 800 and 900. 


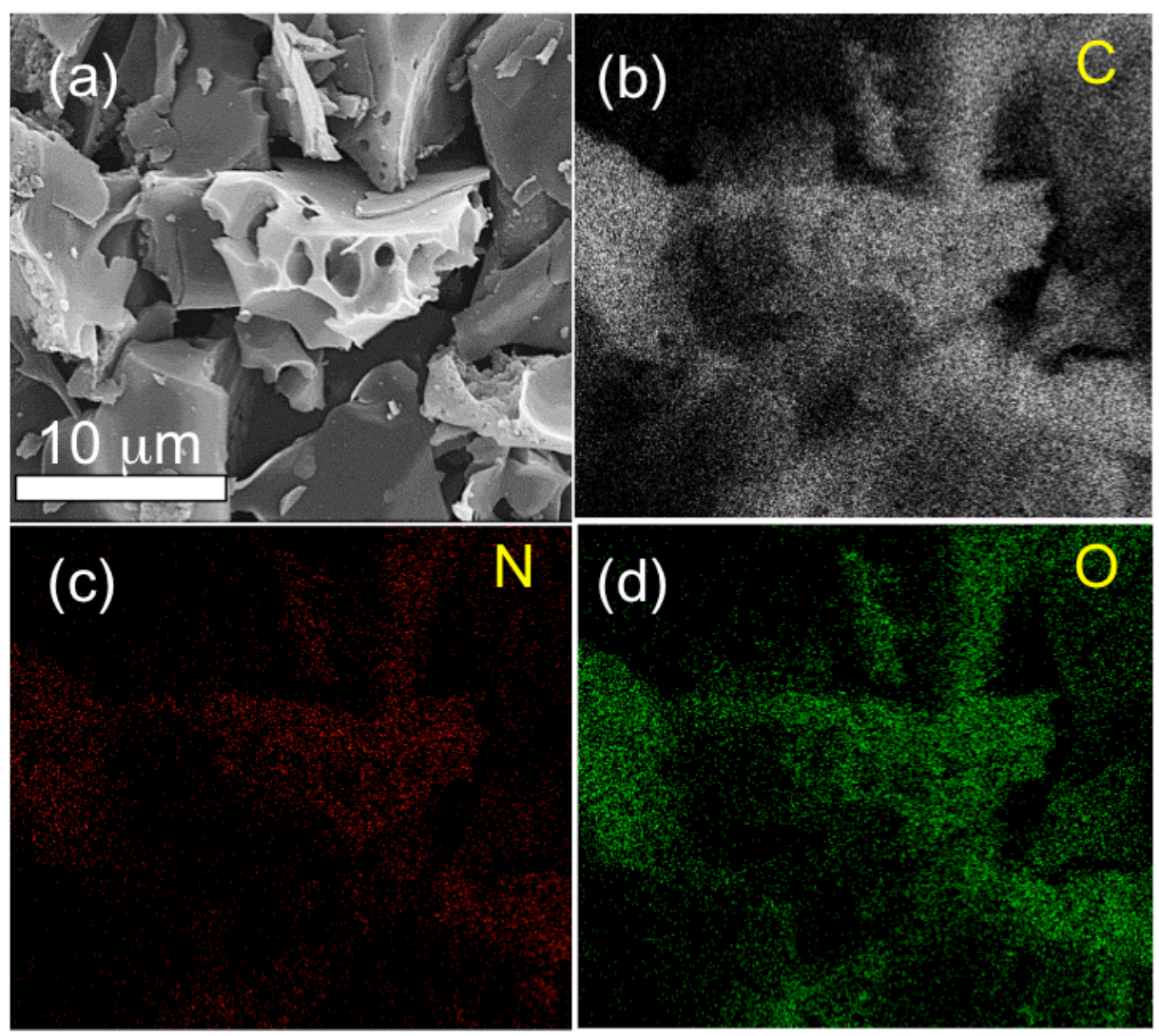

Figure S3. (a) A typical SEM image for the HPC-600 sample. (b-d) The corresponding EDX mapping images for carbon, nitrogen and oxygen, respectively. 


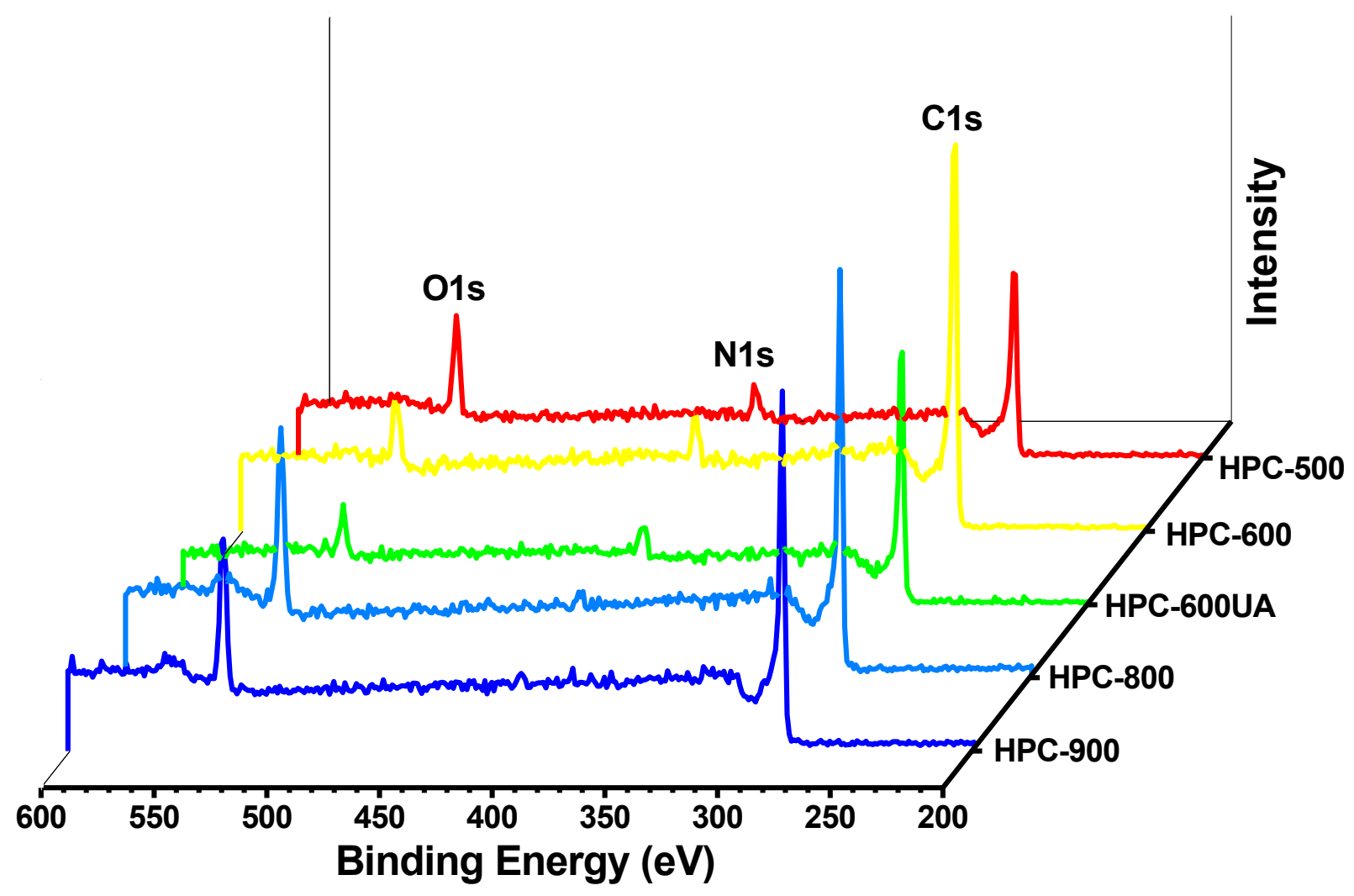

Figure S4. XPS spectra of HPC samples in which signals corresponding to C1s, N1s, and O1s nuclei are highlighted with orange, cyan and pink color, respectively. 


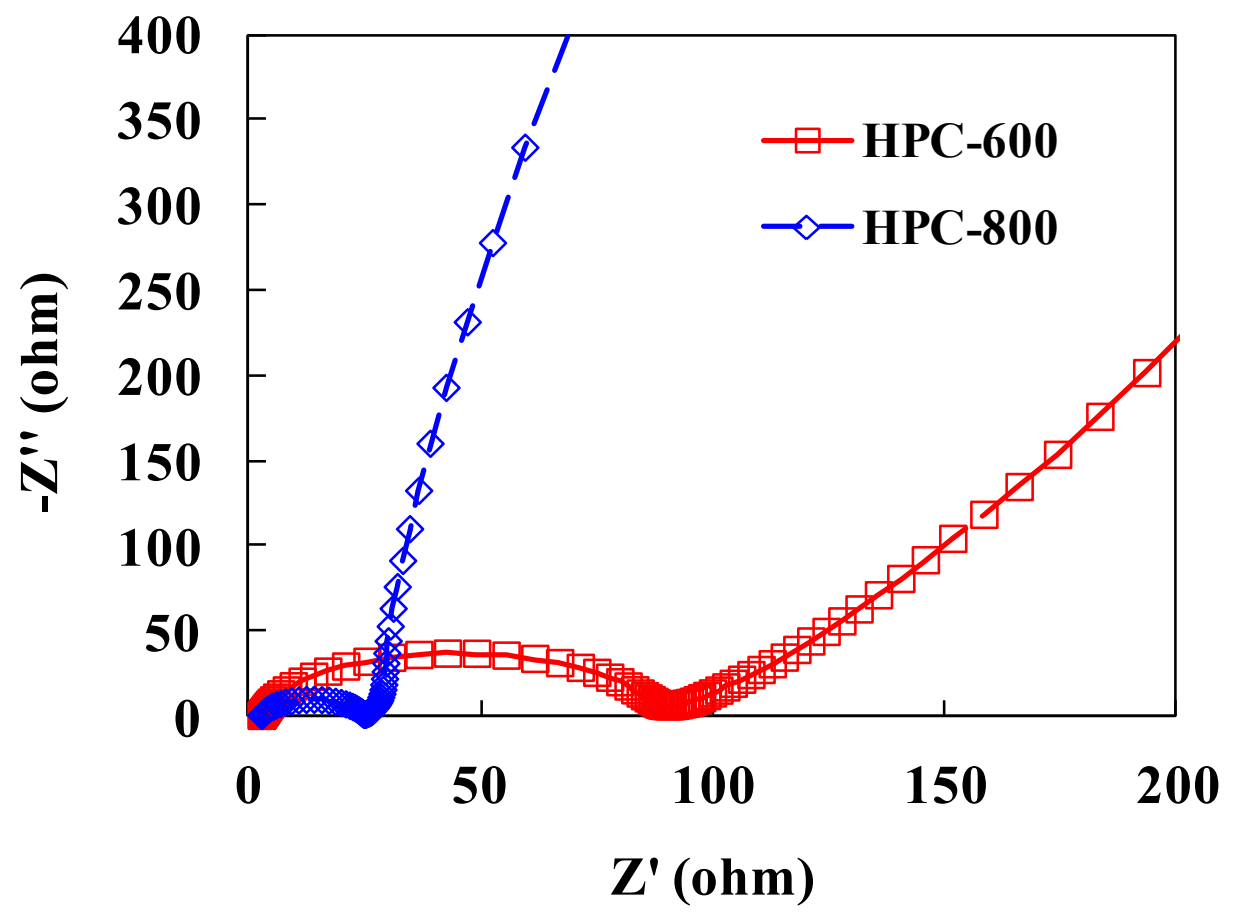

Figure S5. The Nyquist plot of HPC-600 and HPC-800 in $1 \mathrm{M} \mathrm{NaCl}$ aqueous solution at a high frequency range. 


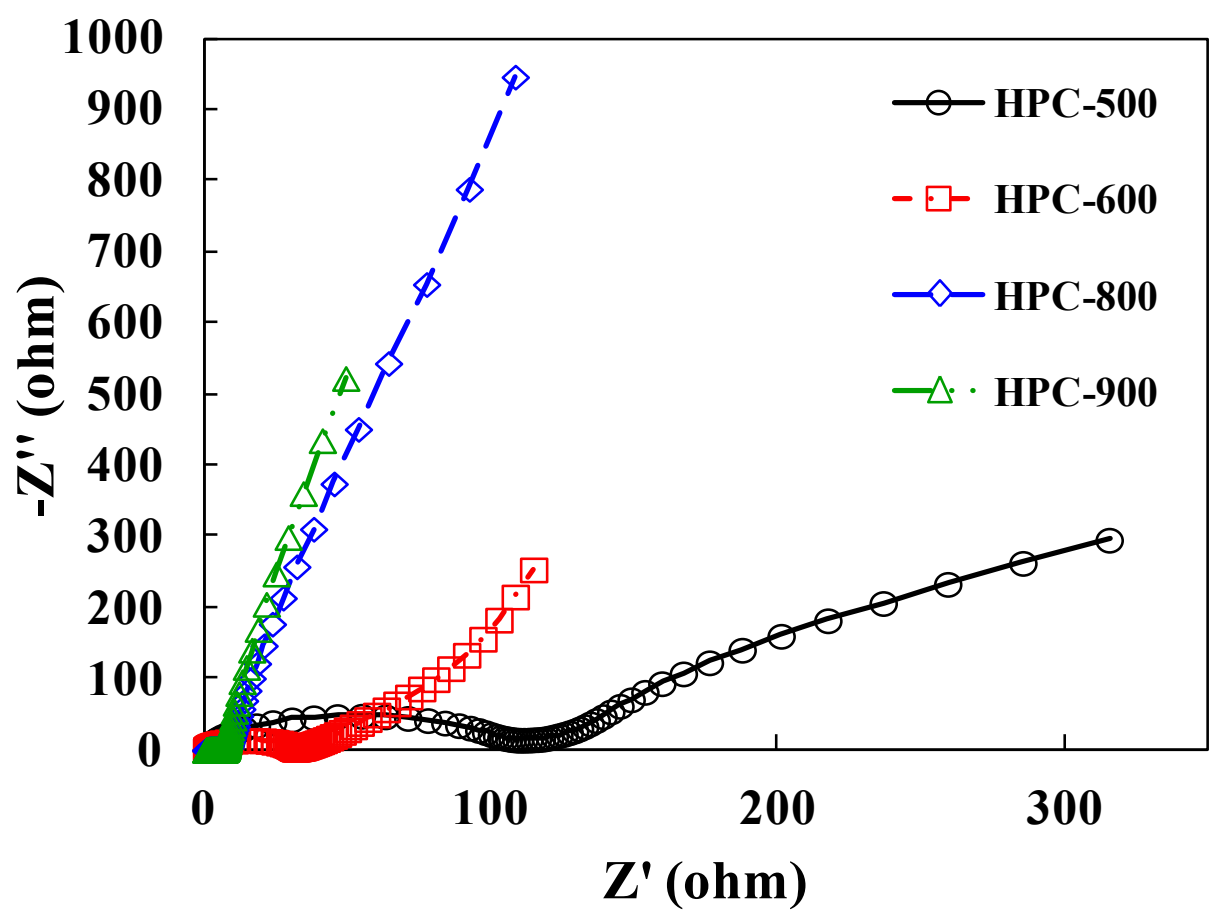

Figure S6. The Nyquist plots of HPC-500, HPC-600 and HPC-800 electrodes in $1 \mathrm{M} \mathrm{H}_{2} \mathrm{SO}_{4}$ aqueous solution. 

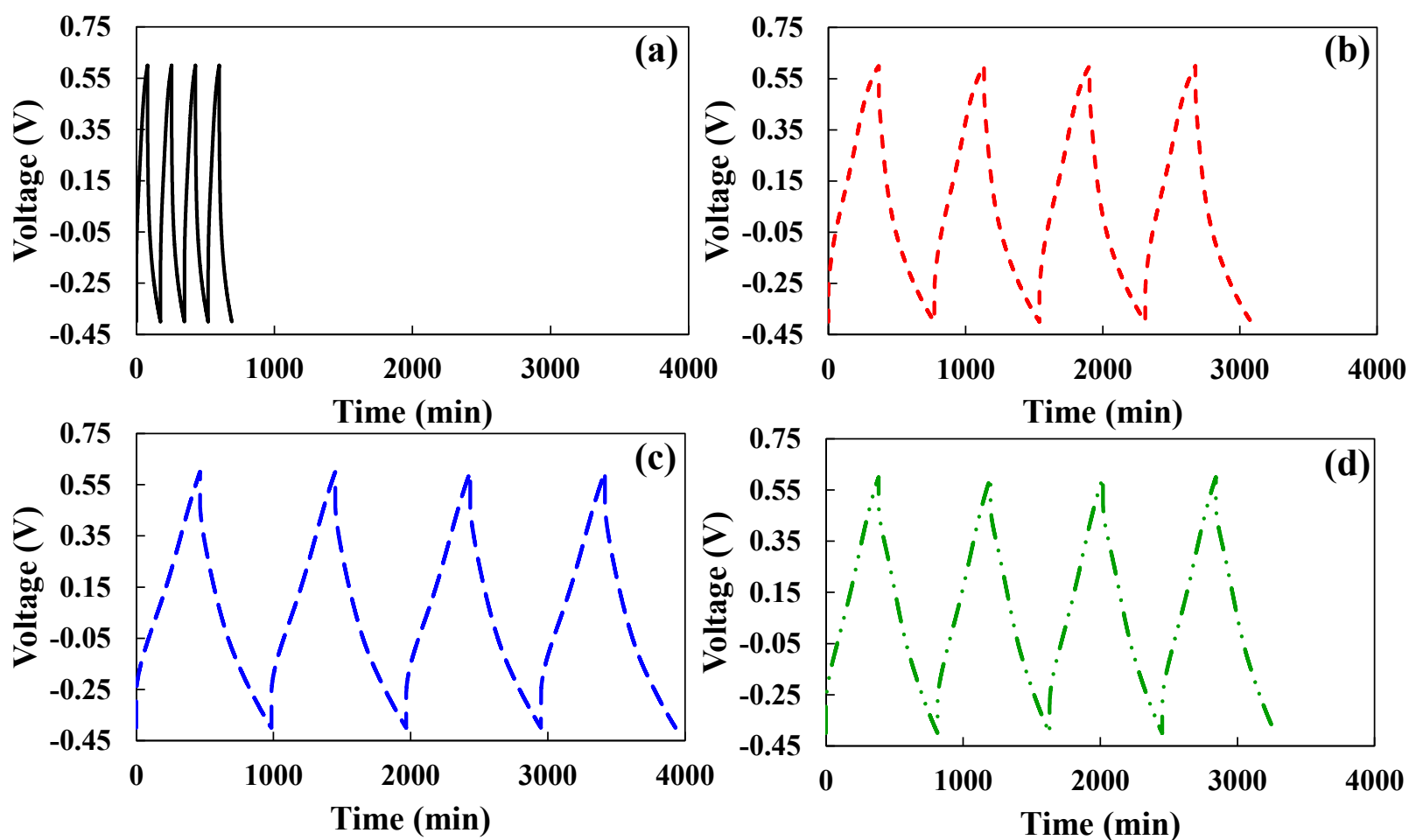

Figure S7. Continuous galvanostatic charge/discharge (GC) of HPC-500 (a), HPC-600 (b), HPC-800 (c), and HPC-900 (d) electrodes at a constant current load of $100 \mathrm{~mA} / \mathrm{g}$ in a $\mathrm{NaCl}$ aqueous solution $(1 \mathrm{M})$. 

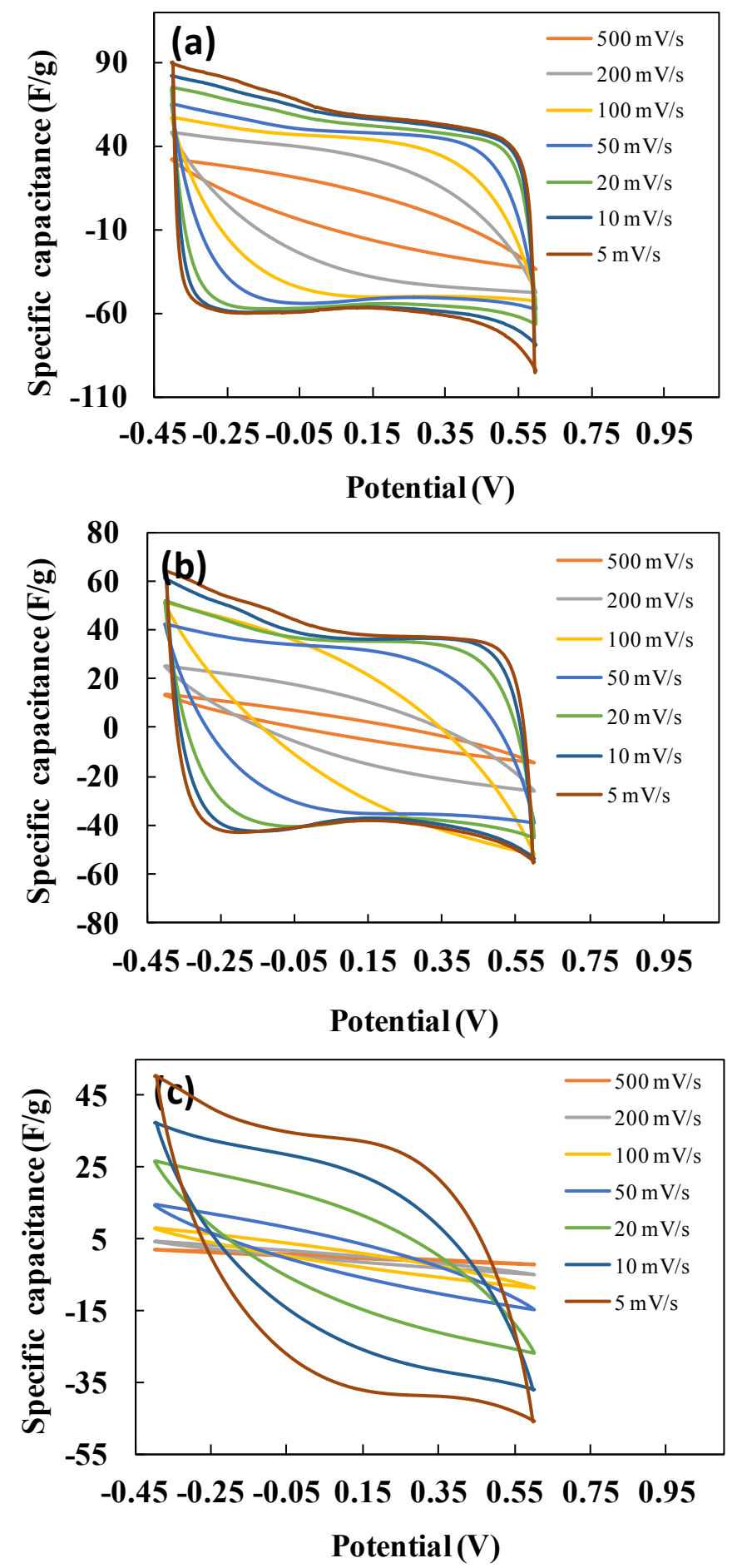

Figure S8. CV curves of HPC-800 at various scan rates $(5-500 \mathrm{mV} / \mathrm{s})$ in $1 \mathrm{M}$ (a), $0.1 \mathrm{M}$, and $0.01 \mathrm{M}(\mathrm{c}) \mathrm{NaCl}$ solution. 

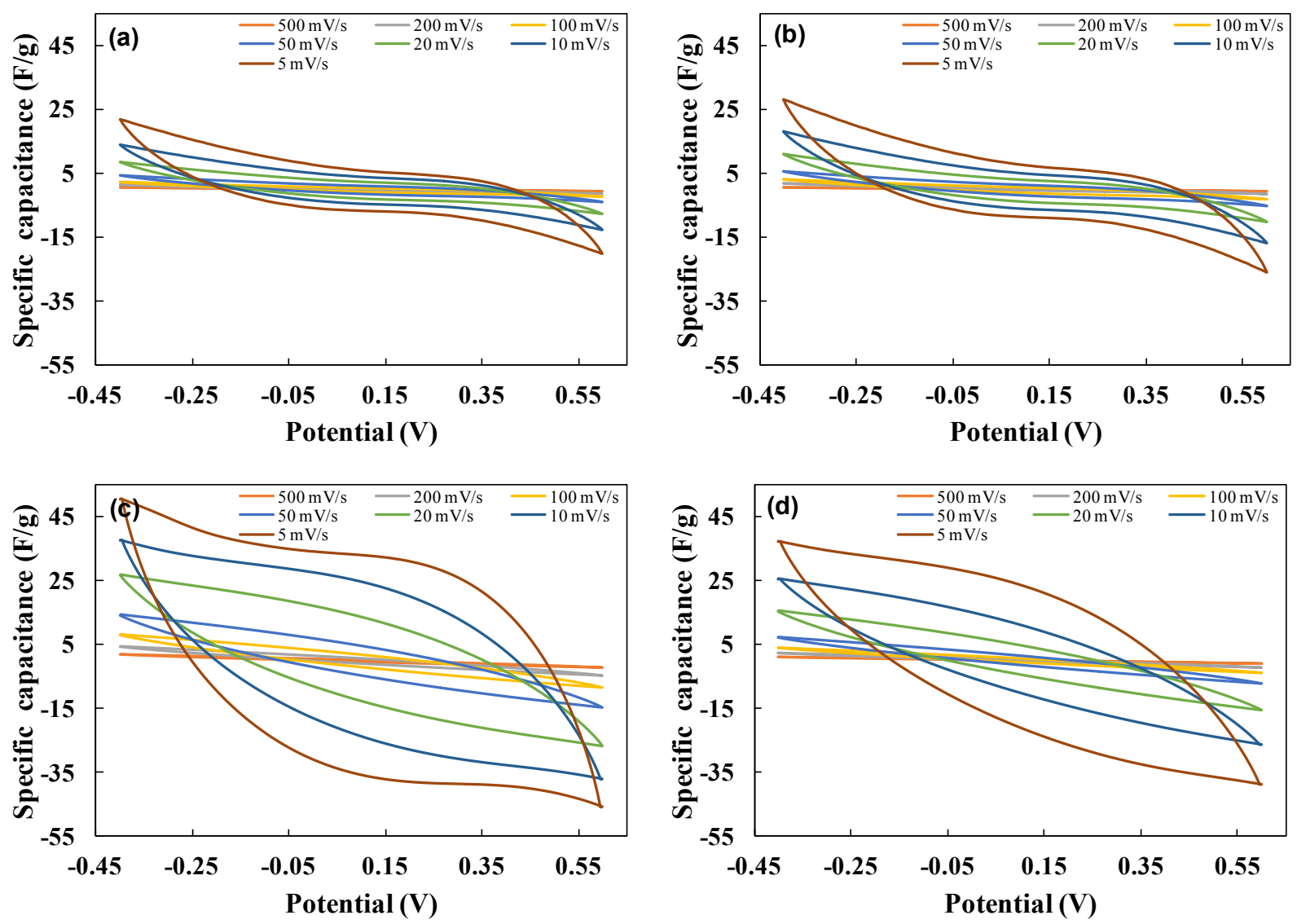

Figure S9. CV curves of HPC-500 (a), HPC-600 (b), HPC-800 (c), and HPC-900 (d) in 0.01 M $\mathrm{NaCl}$ solution at various scan rates ranging (5 to $500 \mathrm{mV} / \mathrm{s}$ ). 


\section{Reference:}

[1] X. Wen, D. Zhang, T. Yan, J. Zhanga, L. Shi, J. Mater. Chem. A, 2013, 1, 12334-12344.

[2] X. Wen, D. Zhang, L. Shi, H. Wang, J. Zhang, J. Mater. Chem. 2012, 22, 23835.

[3] H. Wang, D. Zhang, T. Yan, X. Wen, J. Zhang, L. Shi, Q. Zhong, J. Mater. Chem. A, 2013, 1, 11778-11789.

[4] L. Zou, L. Lib, H. Song, G. Morrisa, Water Res. 2008, 42, 2340-2348.

[5] H. Li, L. Zou, L. Pam, Z, Sun, Environ. Sci. Technol., 2010, 44, 8692-8697.

[6] G. Wang, Q. Dong, Z. Ling, C. Pan, C. Yu, J. Qiu, 2012, J. Mater. Chem. 2012, 22, 21819.

[7] R.T. Mayes, C. Tsouris, J. O. Kiggans Jr., S. M. Mahurin, D.W. DePaoli, S. Dai, J. Mater. Chem. 2010, 20, 8674-8678. 